Яловий Г.К.

доктор економ. наук, професор

Срешко Ю.О.

канд. економ. наук, доцент

Національний технічний університет Украйни «КПІ»

\title{
МЕТОДОЛОГІЯ НАУКОВО-ТЕХНОЛОГІЧНОГО РОЗВИТКУ В КОНЦЕПЦІЇ ПОСТІНДУСТРІАЛЬНОГО СУСПІЛЬСТВА
}

\author{
МЕТОДОЛОГИЯ НАУЧНО-ТЕХНОЛОГИЧЕСКОГО РАЗВИТИЯ В \\ КОНЦЕПЦИИ ПОСТИНДУСТРИАЛЬНОГО ОБЩЕСТВА
}

\section{THE METHODOLOGY OF SCIENTIFIC AND TECHNICAL DEVELOPMENT IN A POST- INDUSTRIAL SOCIETY CONCEPT}

У статті розглядається проблема трансформації на фоні інформатизації національної економіки, яка впливає безпосередньо на базові для неї відносини - відносини у сфері регулювання науково-технологічного стійкого розвитку, що приводить до зміни в масштабах, формах $i$ структурних зрушеннях. Теоретико-методологічний аналіз відносин категорії «розвиток» крізь призму концепції постіндустріального суспільства дозволив переосмислити нові реалії стосовно науково-технологічного розвитку, з'ясувати детермінанти, які визначають подальшу інтелектуальну активність людського капіталу. Визначено роль $i$ обтрунтовано значення інтелектуальної активності, засновану на знаннях, усвідомлену, морально-зорієнтовану спроможність збирати, накопичувати і переробляти все наростаючі потоки інформачії. Підхід до аналізу економічних процесів з позииії суперечливої єдності науково-технологічного розвитку й конкуренції, як різних, але взаємообумовлених систем обміну й координації економічної діяльності має фундаментальне теоретико-методологічне значення.

Ключові слова: сталий розвиток, постіндустріалізм, інформаційна парадигма, інтелектуальна економіка, технологічний детермінізм, гомеостатична система.

В статье рассматривается проблема трансформащии на фоне информатизации национальной экономики, которая влияет непосредственно на базовые для нее отношения отношения в сфрере регулирования научно-технологического устойчивого развития, что приводит к изменению в масштабах, формах и структурньх сдвигах. Теоретикометодологический анализ отночений категории «развитие» сквозь призму концепщии постиндустриального общества позволил переосмыслить новые реалии относительно научнотехнологического развития, выяснить детерминанты, которые определяют дальнейшую интеллектуальную активность человеческого капитала. Определень роль и обосновано значение интеллектуальной активности, основанную на знаниях, осознанную, моральноориентированную способность собирать, накапливать и перерабатывать все нарастающие потоки информации. Подход к анализу экономических процессов с позиции противоречивого единства научно-технологического развития $u$ конкуренции, как разных, но взаимообусловленных систем обмена и координации экономической деятельности имеет фундаментальное теоретико-методологическое значение.

Ключевые слова: устойчивое развитие, постиндустриализм, информационная парадигма, интеллектуальная экономика, технологический детерминизм, гомеостатическая система.

The paper deals with the inquiry on a theoretical problem of national economy transformation against the background of comprehensive informatization, which affects directly its basic relations - 
relations in persistent technological development regulation, which in the end conclude to postulate, forms and structural displacement alternation. Theoretical and methodological analysis of relations in a category "evolution" through the prism of post-industrial society concept allows reconsidering the new realities regarding the technical development and also to emphasize the determinants of further intellectual activity of human capital. There was given the definition of the intellectual activity, which constitutes a supraliminal ability to gather, accumulate and process constantly growing information flows, based on knowledge and attainments, and was determined its role as well. An approach to the analysis of the economic processes from the position of contradictory unity of the science and technology progress and the competition as different, however mutually conditioned systems of the economic activity exchange and coordination, has fundamental theoretic-methodological significance.

Key words: persistent development, informational paradigm, post-industrial society, intellectual economy, technological determinism, homeostatic system

Вступ. В сучасних умовах економічна система України зазнає суттєвих змін, які пов'язані з початком нового етапу розвитку. Ці зміни визначаються новими якісними умовами господарювання та пов'язані 3 розвитком нових галузей виробництва, 3 збільшенням диференціації та інтеграції окремих виробництв, 3 заглибленням міжнародного розподілу праці, необхідністю переходу до постіндустріального і інформаційного суспільства, яка підсилюється залежністю української економіки від світового господарства, розвитком системної економічної глобалізації. Ці фактори разом привели до наростаючого ускладнення структурних складових економіки, яка включає не просто збільшення кількості іiі елементів, а зміну якісних параметрів, ускладнення умов, систем і механізмів їх функціонування і розвитку на різних рівнях економічної системи. Сутність цих змін проявляється у тому, що інформаційна технологічна парадигма охоплює усі сфери і галузі індустріальної економіки, змінюючи іï масштаб, динаміку і внутрішню структуру. Так, наприклад, під впливом науковотехнологічних змін формується сучасний сектор агрокомплексу (заснований на біотехнології та генній інженеріi), інформаційна промисловість (заснована на наукоємних технологіях та інноваційності) і інформаційна сфера послуг (основана на комп'ютерних технологіях, телекомунікаційних зв'язках та інтернеталізації суспільства). Поняття «інтелектуальна економіка», що отримало в останні роки широке розповсюдження в світовій економічній літературі, відображає визнаня того, що наукові знання і спеціалізовані унікальні складові їх носіїв, стають головним джерелом i ключовим фактором розвитку матеріального i нематеріального виробництва, забезпечення стійкого економічного розвитку. Наявність цієї риси в сучасній західній науці визначає формування нового соціального упорядкування [1]. Феномен «нового соціального упорядкування» прийдешньої інформаційної цивілізації інтенсивно вивчається західними вченими в рамках концепції постіндустріального суспільства (Д. Белл, М. Янг, О. Тоффлер, П. Дракер, Т. Сакайя, Т. Стюарт, Л. Едвинсон та інші) та піддається аналітичним дослідженням українських вчених (В.Д. Базилевич, Ю.М. Бажал, Л.М. Смельяненко, М.З. Згуровський, Т.Т. Ковальчук, Ю.М. Пахомов, Н.П. Тарнавська, В.К. Черняк, А.А. Чухно, В.Я. Шевчук та інші).

Нагальна потреба в системних дослідженнях процесу трансформації інформаційного суспільства пов'язана з відсутністю методології пізнання сутності поняття науково-технологічного розвитку, яка представляє собою таку єдність взаємопов'язаних i взаємообумовлених функціональних елементів, які здатні 
відновити розширене відтворення своєї інтегративної якості за рахунок власних фінансових активів.

Постановка завдання. Метою дослідження $є$ теоретичне обгрунтування i визначення поняття «стійкий науково-технологічний розвиток» відносно змін в суспільстві, які пов'язані із заміщенням праці знаннями, тобто в умовах, коли знання залучаються в практичну переробку ресурсів i, саме знання, а не праця виступають в якості джерела вартості. Трудова теорія вартості замінюється теорією «вартості», яка створюється знаннями (knowledge-value). Як підкреслює засновник цієї теорії Т. Сакайя: «Ми вступаємо в новий стан цивілізації, в якому рушійною силою є вартості, створені знаннями» [2]. Як наслідок, економіка перетворюється на систему, що функціонує на засадах обміну знаннями та їх взаємної оцінки.

Методологія. Теоретико-методологічну базу роботи складають праці провідних зарубіжних та вітчизняних вчених. Для досягнення поставленого завдання було використано загальнонаукові методи пізнання, що дозволило виявити сутність та природу поняття “сталий розвиток в постіндустріальній економіці".

Результати дослідження. Структурні закономірності і модернізаційні особливості формування нової науково-технічної бази промисловості України зорієнтовані на національну інноваційну економіку, яка потребує проведення подальшого дослідження 3 урахуванням різноманітності i диференціації взаємообумовлених та взаємопов'язаних зв'язків між структурними компонентами інноваційної діяльності. За даних умов, постає все більш нагальна потреба у постіндустріальній трансформації національної економіки, яка повинна забезпечити активізацію генерації й використання інновацій 3 урахуванням гнучкої взаємодії всіх учасників індустріального і постіндустріального виробництва на основі перетворювання форм технологічного розвитку та державної підтримки модернізаційних процесів за допомогою макросистемних інновацій, що визначають конкурентоспроможність національного виробничого комплексу.

Поглиблення таких гострих соціальних проблем, як загроза техногенних катастроф, забруднення навколишнього середовища, теперішній стан України в світі, ситуація в освітній сфері, енергетична безпека тощо, передбачає розширення кола питань, що постають перед сучасною економікою, яка має набір когнітивних інструментів, що дозволяють не тільки усвідомити проблеми сучасного розвитку економіки, але і конструювати майбутнє, оскільки воно іманентно присутнє в сучасному.

На початку XXI століття, як у науковців, так і у практиків склалася думка про неминучість глибоких змін в процесах і процедурах управління науковотехнологічним розвитком. Основою цієї ситуації стали наступні причини:

- глибокі прогалини у функціонуванні моделі науково-технічного розвитку промисловості України, що з'явились в середині 90-х років минулого століття;

- стрімкі зміни економіки під тиском кардинальної ролі розвитку науки i техніки у процесі розвитку промисловості, суспільства, становлення ринкової економіки; 
- якісно нові вимоги існуючої моделі розвитку, які впливали на зростання кількісних та якісних диспропорцій;

- зростання геоекономічних протиріч і зміна їх якісних параметрів;

- зростання пріоритетності забезпечення модернізаційних перетворень провідних економік світу;

- глобалізація і інтеграція національних економік i, пов'язана 3 цим, поява нових механізмів регулювання соціально-економічного та науковотехнічного розвитку.

Світова економіка зазнала значної перебудови виробничого сектору на новій науково-технічній базі постіндустріального характеру, коли межі поміж окремими технологіями науки і виробництва змінюються, а кінцеві результати повторюються у вигляді інноваційних розробок різних галузей науки і технологій, що кардинально змінюють формування конкурентоспроможності світових товаровиробників. В розвинених країнах безпосередній вплив на матеріальний засіб праці приводять вже не 9/10, як це було в умовах індустріальної економіки, а менш, ніж 1/3 робітників. Знання та творчий потенціал працівників стає рушійною силою інноваційної діяльності, «персоніфікованим» ресурсом. Останні дослідження західних вчених свідчать про стрімке зростання вартості інтелектуальних фондів компаній по відношенню до матеріальних ресурсів i фінансового капіталу. В цілому це співвідношення коливається в межах: 5:1 і 6:1. Визначено, що долар, витрачений на дослідження і розробки, приносить у вісім разів вищий прибуток ніж долар, інвестований в техніку [3-2c.].

Сучасна наука відкриває все більше можливостей для підкорення світу людиною. Історично склалося так, що розвиток науки в цілому відрізняється від розвитку технологій. Процес розвитку науки в загальних рисах починається 3 появою розрізнених і не пов'язаних між собою галузей знань. Пізніше починає відбуватися поєднання наукових дисциплін в більш крупні спеціалізовані асоціації. До процесів поєднання наукових дисциплін відноситься междисциплінарність, кросдисциплінарність, трансдисциплінарність тощо. Проте, розвиток технологій протягом тривалого періоду, як правило, обумовлюється деяким одним ключовим відкриттям або прогресом певної галузі. Сьогодні, завдяки прискоренню науки і техніки, можна спостерігати перетин в часі цілого ряду хвиль науково-технічної революції, що проявляється у випереджаючому розвитку живого знання по відношенню до уречевленого. Живе знання отримало в англійській мові виразну назву «м'якого товару» (soft mare), а друге - «твердого товару» (hard mare) або уречевлених в обладнанні, механізмах знань. «Софтізація» економіки означає домінування творчого потенціалу працівників, наукоємність сучасного виробництва та зростаюче просування творчої потенції людини, иї професіоналізму та ерудиції.

Таким чином, зміни є неодмінною передумовою існування суспільства, заснованого на знаннях, а воно, саме по собі, стає більш динамічним по відношенню до індустріальної стадії розвитку, що мала місце до тепер. Японський вчений Т. Сакайя відзначає, що продукція, яка мала високу вартість, тому що являла собою унікальну технологію, негайно втрачає свою вартість як тільки з’являється нова технологія, що іiі перевершує. Наприклад, коли транзистори отримали повсюдне розповсюдження, вартість радіол впала до надто низької ціни, 
а поява реактивних двигунів стала причиною стрімкого знецінення гвинтових моторів. 3 розвитком текстових процесорів цінність технологій, пов'язаних 3 виробництвом друкарських приладів, швидко знецінюється, а комп'ютерне програмне забезпечення нерідко втрачає свою вартість за один-два роки. Т. Сакайя пише, що вартість, створена знаннями, подібна до зірки, що падає та горить яскраво лише тоді, коли проходить через соціальні обставини та суб'єктивні фактори, що дозволяють їй світити яскравіше за інших [2-с.337-371].

Теорія постіндустріального розвитку базується на теорії позитивізму, розглядає формування i розвиток суспільства на основі процесу наукового пізнання, технології суспільного виробництва. Як зазначає В. Іноземцев «теорія постіндустріального суспільства є сьогодні єдиною соціальною метатеорією, яка повною мірою сприйнята світом» [4]. Наукова популярність та авторитет цієї теорії обумовлений і тим, що їі розвиток відбувається природно, еволюційно, не допускаючи ідеологічного протиборства, не кидаючи виклик жодному із напрямів західної суспільствознавчої традиції. Спираючись на закономірності розвитку продуктивних сил технологічних способів виробництва, вона визначає стадії суспільного розвитку, цивілізаційного прогресу. Проте, теорія постіндустріального суспільства не обмежується технологічним детермінізмом, а забезпечує широкий погляд на розвиток суспільства, перехід від суспільства матеріальної продукції до його сервізації, розкриває роль і значення інформації, науки та освіти, аналізує зміну співвідношення між матеріальним виробництвом і сферою послуг, роль людини, розвиток їі як особистості, перетворення праці у творчу працю і становлення нової постматеріальної мотивації людей, розгортання демократії суспільства та удосконалення політичної системи, розвиток державного регулювання та прогнозування економіки, культури та інших сфер людської діяльності. Досвід показує, що теорія постіндустріального суспільства не протистоїть і не заперечує інших теорій, а інтегрує їх, збагачує свій зміст та методи дослідження суспільства, перетворюються на важливий і ефективний засіб пізнання тенденцій у розвитку суспільства. Усе це зумовлює необхідність вивчення і усвідомлення переваг і вад теорії постіндустріального суспільства, використання iї великих можливостей у пізнанні світових тенденцій, проводенні обгрунтованої й ефективної політики трансформації науково-технологічного розвитку в цілому.

Загальнометодологічною основою концепції «постіндустріального суспільства» $\epsilon$ еволюційний підхід до історичного розвитку i принцип технологічного детермінізму. Сам термін «постіндустріалізм» був запроваджений у науковий обіг англійським вченим А. Пенті ще на початку ХХ ст. Він дав і його перше визначення: «стан суспільства, яке постане після розвалу індустріалізму». Він пропонував використати цей термін для роздумів про майбутнє у зв'язку 3 тим, «що індустріалізм приречено» [4-с.14].

Як сформована концепція, «постіндустралізм» склався в 70-х pp. і пов'язаний 3 ім'ям професора соціології Гарвардського університету Даніеля Белла. В 1973 р. Д. Белл опублікував працю «Настання постіндустріального суспільства», в якій оприлюднив найновіший, удосконалений варіант концепції. Розвиваючи концепцію постіндустріального суспільства, Д. Белл зазначає, що «оскільки ідея постіндустралізму ... є суспільним передбаченням щодо змін у 
суспільному устрої західного суспільства і такі зміни в соціальних системах $€$ великомасштабними й вони не дають нам змоги встановити окремі деталі «майбутніх соціальних устроїв» [5- с.214], то дана концепція, а не картина специфічного конкретного суспільства як «деяка парадигма, соціальна схема, яка виявляє нові осі соціальної організації та стратифікації в розвиненому західному суспільстві» [5 - с.215].

Д. Белл намагається наслідувати логіку соціального аналізу і навіть заявляє, що всі ми «постмарксисти», разом 3 тим, виступає категорично проти «моністичного підходу» до вивчення закономірностей суспільного розвитку , яке у марксистському вченні визначається тільки діалектичною єдністю продуктивних сил i виробничих відносин. Д. Белл заявляє, що недоліком марксистського вчення про заміну формацій $\epsilon$ те, що концептуальна схема суспільного розвитку будується навколо осі відносин власності, а для характеристики капіталізму така вісь непридатна. Щодо теорії монізму, яку використовував К. Маркс, то усі недоліки класичної політичної економії пов'язані, власне, з непослідовним приведенням двох принципів: 3 недостатнім відокремленням внутрішніх передумов капіталістичного виробництва від зовнішніх, а також, із непослідовним зведенням особливих економічних явищ до їх загальних підвалин, й виведення їх визначеності з цієї загальної основи. «Усі товари, - пише К. Маркс, - можуть бути зведені до праці, як до того, що в них єдине». Що Д. Рікардо не досліджує, так це - тієї специфічної форми, в якій праця виявляє себе як єдине ціле в товарах тому, перетворення товару в гроші виступає у нього як щось тільки формальне, що не проникає глибоко до внутрішньої сутності капіталістичного виробництва (6 -127c.).

На думку Д. Белла перехід від «індустріального» до «постіндустріального» суспільства зумовлюється не стільки матеріальними факторами, скільки соціальними інститутами. Він висуває ідею, що соціальні устрої методологічно ним розглядаються не як відображення соціальної дійсності, а як «концептуальні схеми», покликані добирати окремі атрибути із складної дійсності та групувати їх під спільною рубрикою з тим, щоб розрізняти подібності та відмінності. Такі концептуальні схеми грунтуються на осьовому принципі (тобто, на «основоположній соціальній зміні, специфічно визначеній характеристиці соціальної системи» [9-214c.] та мають осьову структуру, що покликано замінити принцип причинної обумовленості принципом центральності, тобто визначити «організуючу конструкцію суспільства та спонукаючий до дії принцип, який $\epsilon$ первинною логікою для усього іншого». [7-202с.]. Такий підхід дозволив Д. Беллу виділити три такі основні форми суспільного устрою, як доіндустріальне, індустріальне та постіндустріальне суспільства [7-206с.]. Ці типи суспільного устрою протиставляються один одному в кількох найважливіших аспектах (табл.). Залежно від вибору осі, історію суспільства можна розглядати по-різному: як еволюцію форм власності, його політичну організацію або ж за принципом культурних традицій. Д. Белл бере за основу схему побудови суспільства навколо «осі типів виробництва і використовуваних знань». У визначенні вирішальної ролі наукових знань, саме Д. Белл бачить докорінну різницю між своєю концепцією і поглядами прибічників «індустріалізму», які всі суспільні зміни виводять лише 3 прогресу техніки і технології. 


\section{Характеристика форм суспільного устрою}

\begin{tabular}{|l|l|l|l|}
\hline \multicolumn{1}{|c|}{ Показники } & Доіндустріальне & Індустріальне & Постіндустріальне \\
\hline $\begin{array}{l}\text { Основний виробничий } \\
\text { ресурс }\end{array}$ & Сировина & Енергія & Знання \\
\hline $\begin{array}{l}\text { Характер виробничої } \\
\text { діяльності }\end{array}$ & Добування & Виробництво & Обробка \\
\hline Технологія & Трудомістка & Капіталомістка & Наукомістка \\
\hline Основний тип взаємодії & Людина-природа & $\begin{array}{l}\text { Людина - } \\
\text { перетворена } \\
\text { людиною природа }\end{array}$ & Людина-людина \\
\hline
\end{tabular}

Визнаючи знання, що $\epsilon$ необхідними для розвитку суспільства, їх науковий, а що ще «важливіше, теоретичний характер, тобто як вісь» постіндустріального суспільства, Д. Белл зосередив свою увагу на розгляді змін, що відбуваються насамперед у соціальній структурі сучасного західного суспільства (яка включає економіку, технологію, систему зайнятості), вважаючи, що саме ці зміни в політиці та в культурі, принаймні «поставлять питання для решти суспільства». Ці питання мають таку форму: а) стосовно, власне, соціальної структури: чому індивіди в новому суспільстві мають 3 нею погоджуватися; б) стосовно політики: як нова технічна еліта співіснуватиме 3 політичною; в) стосовно культури: як узгоджуватиметься антиномічність і антиінституційність культурних тенденцій з новими способами життя. «Спосіб, у який перетворюється економіка й перероблюється система зайнятості, а також нові співвідношення між теорією та емпірією, особливо між наукою і технологією» [7-206с.], потенційно включають п'ять основних вимірів компонентів постіндустріального суспільства: 1. економічна сфера: перехід від економіки виробництва товарів до економіки послуг; 2. поділ населення за родом занять: перевага професійно-технічного класу; 3. осьовий принцип: провідна суспільна роль теоретичного знання як джерела нововведень та політичних формувань; 4. орієнтація на майбутнє: контроль технології та технологічної оцінки; 5. ухвалення рішень: створення нової інтелектуальної технології [12-294].

Таким чином, центральна ознака постіндустріального суспільства - це панування науки, освіти, наукових знань i, на цій основі, технологічна сторона становлення нового суспільства: «Якщо ми бажаємо зрозуміти, що таке сучасне суспільство і яким чином воно перетворилося за останні 200 років 3 індустріального в постіндустріальне, ми повинні розібратися в еволюції техніки, насамперед у тому, як машинна технологія поступилася інтелектуальній... Сьогодні крива технічного прогресу круто пішла до гори, а це свідчить про те, що ми переживаємо третю за рахунком всесвітню технологічну революцію» [8-с.208].

Постіндустріальне суспільство - це новий принцип соціальнотехнологічної організації та новий тип життя, який витісняє індустріальну систему. Це суспільство, засноване на послугах, i, насамперед послугах освіти, охорони здоров'я, аналізу і планування, програмування тощо. Це початок вступу в інформаційну еру: «нова інформаційна ера базується не на механічній техніці, а 
на інтелектуальній технології, що дозволяє нам свідчити про новий принцип суспільної організації та соціальних перемін. Це також ставить за основу теоретичні знання в якості джерела оновлення i зміни природи технічного прогресу. Так само, це робить значущість ідею глобалізації, яка міняє умови прогресу: це єдина система господарства, об'єднання ринків капіталу, валют i товарів... Кордони між країнами практично зникли. Капітал направляється туди, де (при наявності політичної стабільності) є найбільша віддача інвестицій або добавленої вартості» [10-с.327].

Концепція постіндустріального суспільства не може бути однозначно віднесена ані до економічної, ані до соціальної, ні до політичних наук. Її, відносно відособлене, положення визначається глобальністю методологічних принципів та масштабом охоплюваних проблем. При цьому, концепція постіндустріального суспільства має внутрішні суперечності. Так, неоднозначність теоретичних підходів щодо переходу суспільства і економіки до постіндустріальної стадії розвитку, визначаються трьома підходами за домінуючим критерієм. Прихильники першого підходу підкреслюють значимість переходу від промисловості до сектору послуг (Д. Белл, Г. Эстепин-Андерсен); прибічники другого підходу відзначають зміни характеру промислового виробництва від масового виробництва до гнучкого спеціалізованого - у відповідь на технологічні новації (М. Кастелльс, А. Амин, М. Пиоре. Ч. Сабель, Д.Соски); предметом особливої уваги в межах третього підходу остають знання та їх значимість, що постійно зростає для економіки (П. Бергер, Д. Ходгсон). Схожі суперечності підходів усуваються, якщо звернутися до практики, де одночасно спостерігаються усі три зазначент підходи: зростає активність у секторі послуг, визначаються зміни у системі виробництва, а також, підвищується значимість знань.

Відзначені критерії переходу до постіндустріальної стадії, в той же час, виступають в якості фундаментальних ознак-характеристик постіндустріального суспільства. Критики концепції постіндустріалізму вважають слабкою стороною даної концепції недостатню глибину іiі теоретичних вибудов, зміщення акценту на якісні характеристики постіндустріального суспільства без розкриття механізмів переходу суспільства і економіки до постіндустріальної стадії розвитку [10 - с. 2930; 149-151].

Генеза та подальше розгортання концепції постіндустріального суспільства були відгуком на нові реалії соціально-економічного розвитку. У дослідженнях постіндустріальних тенденцій в цілому, можна визначити вектор на дроблення i деталізацію даної проблематики. До провідних наукових експертів можна віднести В. Іноземцева, А. Бузгаліна, В. Базилевича, А. Колчанова, Т. Ковальчука, В. Черняка, Ю. Пахомова, А. Чухно. В їх працях не тільки розкривається методологія дослідження постіндустріального суспільства, проблеми адаптації економіки України до нових умов у цілому, але і окреслюється увага щодо проблематики науково-технологічного розвитку i економічнх відносин, що регулюють ці процеси.

Так, наприклад, вчені звертають увагу на те, що побудова постіндустріального суспільства можлива лише на базі розвиненої економіки, яка забезпечує розширене суспільне відтворення. Як свідчить практика, найбільш конкурентоспроможні країни, що перейшли на стадію постіндустріального 
розвитку використовують у своєму зростанні інновації та продукти НТП. Підтвердженням даної тези слугує індекс Глобальної конкурентоспроможності Всесвітнього економічного форуму. Адже, у першу десятку лідерів рейтингу 2011-2012 рр. увійшли такі країни, як Швейцарія (індекс - 5,74), Сингапур $(5,63)$, Швеція (5,61), Фінляндія $(5,47)$, США $(5,43)$, Німеччина $(5,41)$, Нідерланди $(5,41)$, Данія $(5,40)$, Японія $(5,40)$, Велика Британія $(5,39)$. Таку високу оцінку сформували, саме, їх здобутки у сфері розвитку інновацій. Зокрема, Швейцарія, що посіла перше місце за складовою «фактори інновацій та розвитку» (ранг 5,79), Швеція - 2 місце (ранг 5,79), Фінляндія - 4 місце $(5,56)$. За результатами оцінювання індексу Глобальної конкурентоспроможності 2011-2012 рр., Україна посіла 82-ге місце серед 142 країн з індексом конкурентоспроможності 4.0 [9], що доводить глибоку необхідність використання інновацій у виробництві, їх державної підтримки та формування сприятливого інноваційного середовища.

Ще одна складова, яка вимагає комплексного розв'язання не лише проблем випереджальної модернізації і нових знань щодо уречевлених, прискореного формування людського капіталу в науково-технічній, технологічній, економічній, фінансовій, екологічній діяльності, а й відображає сам процес необоротності закономірних змін, які нагромаджуються в системі розвитку наука - техніка виробництво, є категорія «розвиток». Тема «розвитку (модернізації)» може видатись черговою та традиційною. Але це не так. Дійсно, в 50-70 роках минулого століття, так звані ідеї development studies йшли нескінченним потоком в науковій літературі - як іноземної, так і вітчизняної. 3 часом, дослідники більше писали про «пристосування (accommodation), «виживання» за інших умов в зростанні, ніж про розвиток. Створена 10-15 років тому, концепція «сталого розвитку» не одразу стала виразним замінником. Отже, переосмислення цього фундаментального соціологічного поняття «розвиток (модернізація)» $\epsilon$ необхідним, в зв'язку з тим, що сучасна наукова думка дає чимало підвалин. До них відносяться, зокрема, концепція універсальної еволюції (Е. Ян), в рамках якої «розвиток» означає окреслену соціальну спрямованість еволюції; розуміння як цілеспрямованої діяльності людини (школа Г. Щедровицького) i людського капіталу як суб’єкта розвитку (роботи Е. Сайко) тощо. Таким чином, поняття «розвиток» можна розглядати як категоріальну конструкцію, яка являє собою сукупність різноманітних за вектором і об'єктами змін і дає уявлення про роботу формування системи: наука - техніка - виробництво. Провідна ідея «розвитку» формувалась в людській свідомості і науковому світогляді протягом століть. Значну роль в розробці ідеї розвитку відіграла філософська думка, яка в поняття «розвиток» вкладає, насамперед, особливий тип змін, а також невідривність від руху (рис.1). Але, під цим треба розуміти не окремі зміни, а безліч, комплекс, систему змін в структурі елементів, тобто в рамках якості підсистеми даної матеріальної системи. Композиція системи: наука - техніка дозволяє визначити всі різновиди процесу розвитку, а саме: за лініями, які підіймаються або сходять, рухами зворотні і тупикові, циклічні або маятникові, а також інверсійні або безвекторні рухи. 


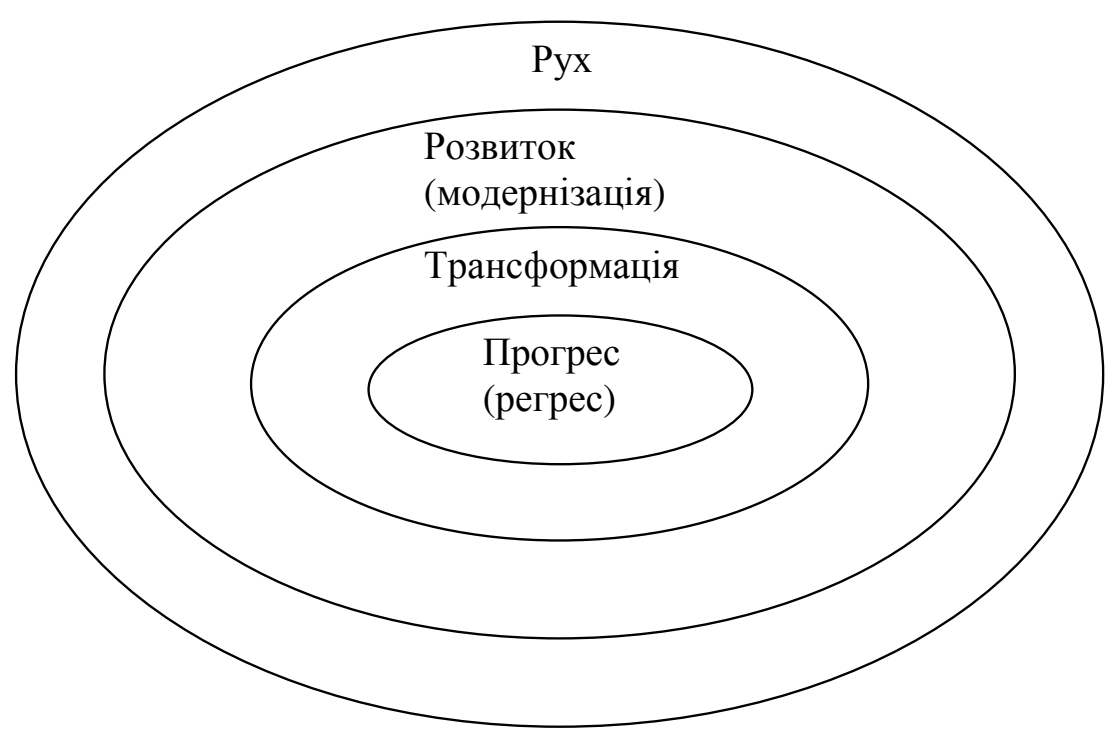

Рисунок. Модель співвідношення рух-прогрес.

Процес розвитку побудовано на трьох взаємозалежних властивостях: незворотність, направленість і закономірність змін матеріального об'єкту. Тільки одночасна наявність усіх трьох властивостей виділяє процес розвитку серед інших змін: зворотність змін характеризує процеси функціонування (циклічне відтворення системи); відсутність закономірностей характерно для випадкових процесів катастрофічного типу; при відсутності направленості зміни не зможуть накопичуватися, i тому процес втрачає єдину внутрішнє характерну для розвитку взаємопов'язаність. Внаслідок розвитку виникає новий якісний стан об'єкту, який виступає як зміна його складу або структури (тобто, виникнення, трансформація або зникнення його елементів і зв'язків). Суттєву характеристику процесу «розвиток» складає час: по-перше, всякий розвиток здійснюється в реальному часі; по-друге, тільки час виявляє направленість розвитку.

Як філософська концепція, ідея «розвитку» найбільш розгорнуто була сформульована Г. Гегелем. Раціональний зміст його теорії полягав в тому, що за законами діалектики розвиваються зміст, система ідей або теорія. Оскільки, поміж мисленням и свідомістю в філософії Гегеля постулюється тотожність, то закони діалектики виявляються придатними і до свідомості [11- 19с.]. Сукупність принципів діалектики, які лежать в основі процесу розвитку визначаються: а) загальний взаємозв'язок усіх явищ; б) загальність руху і розвитку; в) джерело розвитку - становлення й розв'язання протиріч; г) взаємозв'язок кількісних $\mathrm{i}$ якісних змін як прояв механізму розвитку; д) розвиток через заперечення; е) заперечення як прояв направленості процесу розвитку; ж) протиріччя спільності загального і одиничного, сутність і з'явлення форми й змісту, необхідності й випадковості, можливості й дійсності. Усі принципи діалектики тісно пов'язані один з одним через те, що вони відображають різні аспекти і сторони єдиного процесу розвитку. Але цей взаємозв'язок ієрархічний, тому що базовим фундаментальним принципом $є$ єдність і боротьба протилежностей. Його зміст 
розкривається в дії двох других: взаємодії кількості і якості або заперечення одна одної стадіями розвитку об'єкта, сутність яких, виявляється як проявлення негативного принципу протиріччя. Протилежності, у визначених умовах, збігаються, тобто переходять одна в одну. I у взаємовідносинах кількості і якості та послідовних запереченнях - така ж форма: кількісні зміни слугують причиною змін якісних та навпаки, стадії, що заперечують одна одну, у розвитку об'єкту зливаються в синтезі на наступному щаблі тощо.

Направленість розвитку, для якої характерний перехід від нижчого до вищого, від менш досконалого до більш довершеного, називається прогресом. Поняттю "прогрес" протилежне поняття "регрес". Для регресу характерні поняття: деградації, повернення до форми і структури, які себе пережили. Діалектично протилежні прогрес і регрес, пов'язані між собою, нерозривно, включені одне до іншого. Кожен прогрес в органічному розвитку є, разом 3 тим, i регресом тому, що він закріплює односторонній розвиток і виключає можливість розвитку в інших напрямках.

Однак, поняття «розвиток» значною мірою передбачає можливість існування певної стохастичності (тобто, випадковості) i невизначеності. Це зумовлено, головним чином, тією обставиною, що зміни, які спричиняють розвиток, часто являють собою піонерні процеси. Вони відбуваються в середовищі, стан якого не відомий заздалегідь і залежить від взаємодії значної кількості випадкових факторів. Поява стохастичності (хаоса) $є$ внутрішньою властивістю системи і не пов'язана 3 дією будь-яких, апріорі випадкових, сил. Найбільш важливою обставиною $є$ не те, що при визначених умовах може народжуватися хаос (безладдя), а те, наскільки це типово для системи загального виду. Хаос (як внутрішня властивість системи) виникає майже завжди та майже всюди. І якщо ми його не завжди виявляємо, то тільки тому, що він виникає або в дуже вузькій області параметрів, або проявляється протягом значного проміжку часу, або вуалізується іншими, більш потужними процесами.

Поширеним в науковій літературі є лінійне тлумачення модернізації як процесу трансформації об'єкту. Розрізняють два види модернізації: органічну та неорганічну. Органічна модернізація відбувається завдяки ресурсам власного розвитку, підготовлена внутрішньою еволюцією суспільства. Вона починається не 3 економіки, а 3 культури та зміни суспільної свідомості. Неорганічна модернізація $€$ реакцією на досягнення розвинутих країн, формою «наздоганяючого розвитку» 3 метою подолання історичної відсталості. Наприклад, Росія неодноразово намагалася наздогнати розвинуті країни (петровські реформи XVIII ст., сталінська індустріалізація 30-х років XX ст., перебудова 1985 р.). Така модернізація здійснюється завдяки заохоченню інвестицій, імпорту обладнання і технологій, відповідними змінами у соціальній та політичній сферах. Неорганічна модернізація починається 3 економіки та політики, а не з культури. Саме такий вид модернізації властивий пострадянським країнам. Пізніше виникла теорія «запізнілої модернізації». Її автори виходять 3 того, що існує лінійний процес і поступовість стадій розвитку суспільства. Слід брати до уваги й те, що «запізніла модернізація» може поставити суспільство у зовнішню залежність від іншої країни. Серед вітчизняних вчених відсутня єдина думка щодо сутності сучасного українського суспільства i напряму його 
трансформації. За словами А. Гальчинського, Україна поступово просувається до, так званого, соціалізованого капіталізму (Японія, Швеція). За іншими оцінками, українське суспільство $є$ феодолізований капіталізм, який поєднав у собі модернізовані відносини позаекономічного примусу, неринкові зв'язки, як ознаки-атрибути феодальної системи 3 економічною міжіндивідуальною i міжкорпоративною конкуренцією та вільним ринком, як ознаками класичного, ліберального капіталізму».

На наш погляд, розвиток - комплексне поняття, гомеостатична система 3 поліпшеною пристосованістю до зовнішніх умов, система, яка пов'язана 3 перетворенням у внутрішній структурі об’єкта сукупності, функціонально пов'язаних елементів, відносин і залежностей; це спіралевидний рух від простих форм до складних. Траєкторія розвитку знаходиться під впливом двох векторів. Перша складова розвитку - горизонтальна, яка приводить до циклічної повторюваності і заснована на внутрішніх ритмах системи. Друга складова вертикальна, завдяки якій не відбувається загнивання системи. Наступний виток спіралі стоїть вище попереднього. Слушно підкреслюється в літературі, що «розвиток»є така зміна стану, що відбувається за умов зберігання його основи, тобто початкового стану, що породжує нове становище. «Зберігання початкового стану або основи іiі тільки i робить необхідним здійснення закономірностей розвитку» [21]. У конкретній цілісній системі одна природа, одна інтегративна якість, інакше вона перестає бути даною системою. Ведучи мову про розвиток, вислів «зміна якості» належить розуміти не в значенні зникнення у системи іï основної власної якості. Слід розглядати, з одного боку, інтегративну основу конкретної цілісної системи, а 3 іншого - iï підсистему складноорганізовані комплекси елементів, у тому числі стану та стадії, тощо.

Сьогодні, все частіше вживають терміни «економічна стійкість», «сталий економічний розвиток», що набули значення якісно нового аспекту теорії розвитку. Ці терміни застосовуються дослідниками для різних характеристик економічної особливості внутрішнього і зовнішнього середовища суб'єкта управління: економічний сталий розвиток, стійкість розвитку науки і техніки, сталість інноваційної програми розвитку, стійкість функціонування підприємства, тощо. На наш погляд, причини такого широкого використання зазначених понять обумовлені не тільки їх універсальністю, але ісуперечливістю, недоопрацьованістю концепції сталого розвитку, особливо в іiі економічному аспекті, неповнотою інформації щодо здійснення вимірювання рівня стабільності i прийняття позитивних управлінських рішень, відсутністю спільного формалізованого підходу до вирішення цього питання. Домінуюча, до недавнього часу, в економіці парадигма грунтується на деяких положеннях про суспільство, яке будучі ефективним щодо розподілу ресурсів в короткостроковому періоді, менш точне і прийнятне з довгостроковими проблемами сталого розвитку. Але, як показало дослідження літературних джерел, достатньо поширеною думкою $є$ те, що поняття «сталий» $\mathrm{i}$ «розвиток» не протирічать одне одному, тому що розвиток у принципі може бути сталим. Всі автори сходяться в думці, що розвиток - це рух, зміна, а сталість - інваріантність. Іншими словами сталість означає, що окремі характеристики системи залишаються незмінними при усіх варіантах розвитку. Професор А.Г. Мельник для характеристики стійкості системи називає 
наступні параметри: витривалість, толерантність, адаптивність та інші [12 -с.110]. Тому ,однозначним висновком проведеного дослідження $\epsilon$ те, що сталість розвитку - це складний i, однозначно, комплексний термін. В роботі під «стійким розвитком» будь-якого об'єкта дослідження ми розуміємо слабо - структурований (неформалізований) рівноважний стан для забезпечення кількісного і якісного, переважно інтенсивного, диференційованого зростання. Сталість - це суттєва складова процесу розвитку, яку треба сприймати як: а) спроможність системи до відновлювання параметрів після впливу на неї та б) спроможність системи до зберігання параметрів при впливі на неї. Крім того, зниження темпів розвитку неможна однозначно вважати ознакою нестійкості. В зв'язку з тим, що категорія «розвиток» представляє собою суперечливий процес, який може мати протилежну направленість. Розвиток, як нерівномірний процес, включає періоди зростання та спаду. Крім того, можливім є, також, і виділення форм розвитку, які включають кількісні і якісні зміни, позитивні і негативні тенденції економічних процесів. Тому економічний сталий розвиток може вивчатися тільки в динаміці на середньострокових та довгострокових часових інтервалах. Ймовірно, в зв'язку зі скрутністю вимірювання процесу економічного розвитку в економіці, частіше за все аналізують економічне зростання, але воно є тільки одним із можливих напрямків економічної динаміки. Наприклад, економічний цикл характеризується періодичними змінами стадій спаду, депресії, пожвавлення і зростання.

Витривалість - це здатність системи зберігати свої функціональні особливості або можливості їх відновлення при відхиленні умов зовнішнього середовища від оптимальних для неї параметрів. Іншими словами, йдеться про збереження будь-яких форм існування системи (включаючи латентні - тобто, пригнічені, приховані), що дозволяють уникнути необоротного припинення функціонування системи. Таким чином, витривалість - це здатність системи уникати незворотного припинення функціонування під впливом зовнішніх чинників. Як аналоги поняття витривалість по відношенню до різних типів систем використовуються й інші терміни. У техніці користуються поняттям «надійність», «довговічність», в суднобудуванні - «плавучість», «живучість», в інших системах - «толерантність» (терпимість), що означає здатність сприймати ті чи інші несприятливі параметри зовнішнього середовища. В економічних дослідження називають два основні параметри: стабільність і стійкість, які характеризують витривалість. Головна відмінність між ними полягає в тому, що перший характеризує залежність поведінки системи від внутрішніх чинників, а другий від зовнішніх. Таким чином, сталість - це здатність підприємницької структури повертатися в вихідне або близьке, до іiі першочергового стану, положення при будь-яких змінах зовнішнього впливу без втрат фінансового результату або вартості бізнесу. Тому, стійкість - це зовнішнє виявлення внутрішньої властивості системи. Відповідно, щоб підвищити стійкість системи до впливу зовнішньої дії, необхідно $\epsilon$ удосконалення внутрішніх властивостей даної системи. Під економічною стійкістю суб'єкта господарювання пропонується розуміти здатність системи, структури підтримувати беззбитковий рівень економічних показників в довгостроковому періоді за будь-яких змін чинників зовнішнього середовища. Ми пропонуємо в якості таких характеристик використовувати параметри, які характеризують або вартість бізнесу, або доходність. Відповідно, можуть бути 
застосовані як традиційні показники аналізу грошових інвестиційних потоків, так і показники, які характеризуються ефективністю функціонування (EVA, MVA, тощо).

Відкритість економіки України передбачає, що формування іï зовнішньоекономічних зв'язків і внутрішньої соціально-економічної політики, включаючи політику науково-технічного розвитку й оновлення виробництва має відбуватися 3 урахуванням глобалізаційних процесів. Жодна країна сучасного світу, незалежно від іiі ставлення до глобалізації, не може уникнути ії впливу. Термін «глобалізація» вперше ввів у науковий оборот американський вчений Т. Левітт, для визначення нового явища, а саме: злиття ринків, цей процес активно проявився 3 початку 80-х років XX ст. Більш широкого значення термін набув завдяки Гарвардській школі бізнесу. Ініціатива належала консультанту цієї школи, японському вченому К. Оме, який опублікував в 1990 р. книгу «Світ без кордонів». Він виходив 3 того, що світова економіка визначається сьогодні взаємозалежністю трьох центрів - ЕС, США і Японії, і стверджував, що економічний націоналізм окремих держав стає безглуздим, внаслідок того, що економічний клімат на планеті встановлюють «глобальні ТНК». Через те, що процес глобалізації неоднозначний за своїми політичними i соціальноекономічними наслідками і в той же час зачіпає інтереси усіх країн, за проблемою глобалізації проходять незатухаючі дискусії, у ході яких висловлювалися різні думки й оцінки, які носять альтернативний характер. При цьому, вчені, які позитивно оцінюють даний процес, звертають увагу на його економічну складову. Проте, скептики перспективи глобалізації не обмежуються економічними проблемами, а зосереджують увагу на питаннях світоглядного характеру, долях національних культур, історичних традиціях, розвиткові національного духу народів, тощо. За цих обставин, постає завдання дослідження факторів глобалізації та сили їх впливу на науково-технічний розвиток виробництва $\mathrm{i}$ розробки адекватних заходів регулювання науково-технологічного потенціалу та його стійкого розвитку. Тому, нами визначено, що глобалізація - це суттєва складова, яка впливає на стійкий розвиток науково-технологічних відносин. Застосовання такого підходу для нашого дослідження опосередковане тим, що глобалізація гостро підвищує ступінь відкритості суспільної системи в цілому та усіх іï складових підсистем окремо. Це відбивається у інтенсифікації обміну інформацією у глобалізації фінансових і інвестиційних трансакціях, у значному розширенні обміну науковими ідеями, заділами, освітою, технологіями, науковими досягненнями, вченими-мігрантами. Крім наростання відкритості економічних систем, глобалізація викликає підсилення нерівноважності процесів, які відбуваються. Це призводить до незворотності змін у основних сферах загальної діяльності, відносинах поміж окремих держав, взаємозв'язку соціумів в цілому та навколишнього природного середовища. Процес інтернаціоналізації виробничих, наукових, науково-технічних зв'язків не можна повернути назад у планетарному масштабі, що не виключає, безумовно, можливостей тимчасової самоізоляції окремої країни. До того ж, самоізоляція неминуче приведе до деградації. Крім того, у нових реаліях сучасного світу, повна самоізоляція попросту неможлива. Тому, перехідні процеси в економіці бувають доволі різноманітними, але вони, так чи інакше, пов'язані з глобальними якісними 
зрушеннями. Необхідність такого переходу висуває в якості пріоритетної, проблему наукового обгрунтування принципової можливості та шляхів реалізації моделі стійкого розвитку. При цьому, докази необхідності та можливості переходу до стійкого розвитку мають поєднуватися 3 орієнтацією державного регулювання науки, техніки, технології, освіти на нові цивілізаційні цілі. Базис майбутнього суспільства не можливо створити без випереджаючого розвитку науково-технологічного потенціалу та системи освіти.

Висновки. За результатами проведеного дослідження встановлено, що основні риси постіндустріального суспільства зводяться до наступного: 1) провідна роль теоретичного знання становить основу технологічних інновацій; 2) нова інтелектуальна технологія дає змогу знаходити більш ефективні підходи до вирішення технічних, економічних і соціальних проблем; 3) вирішальна роль «носіїв знання» належить професіоналам, технічним спеціалістам, які складають найчисленнішу соціальну групу; 4) посилення ролі та значення науки у технічному переозброєнні суспільства. Найважливішою ознакою нового суспільного устрою є вступ людства в постіндустріальну епоху. Це означає не просто розвиток засобів комунікації, які існували раніше, а виникнення нових принципів соціально-технологічної організації. Нова постіндустріальна епоха, заснована не на механічній техніці, а на інтелектуальній технології, що дозволяє нам сприймати новітній принцип суспільної організації і соціальних змін. Це висуває на визначальне місце теоретичне знання як джерело оновлення, що змінює природу технологічного прогресу.

Теоретичне та практичне значення результатів дослідження полягає в поглибленому аналізі реального стану будови постіндустріального суспільства, що можливе лише на базі розвиненої економіки, яка може забезпечити розширене суспільне відтворення. Як свідчить практика, найбільш конкурентоспроможні країни, що перейшли на стадію постіндустріального розвитку, використовують у своєму зростанні інновації та продукти науково-технологічного розвитку. Це підтверджує індекс Глобальної конкурентоспроможності Всесвітнього економічного форуму, який для розвинених країн в першій десятці складає 5,74 5,39 проти 4,0 для України (83-ге місце серед 142 кран), що доводить необхідність використання інновацій у виробництві, їх державної підтримки та формування сприятливого інноваційного середовища.

Наукова новизна проведеного дослідження полягає в запропонованому методологічному підході до формування концепції ідеї «сталого розвитку», що являє собою складну і одночасно комплексну категорію. В роботі під «стійким розвитком» треба розуміти слабо-структурований (неформалізований) рівноважний стан для забезпечення кількісного i якісного, переважно інтенсивного, диференційованого зростання творчого потенціалу працівників, наукоємності сучасного виробництва.

За сучасни умова, вирішення проблеми забезпечення сталого розвитку потребує періодичного корегування механізму управління сталим розвитком науково-технологічного процесу. Із цього випливає, що механізм управління сталим науково-технологічним розвитком підприємства повинен включати такі елементи: а) оцінку процесу розвитку; б) вибір стратегічного напряму; в)визначення додаткових тактичних пріоритетів розвитку; г) оцінку стратегічного 
й тактичного напрямків сталого розвитку. Перспективним напрямом подальших наукових досліджень визначено проблему розробки управлінських впливів для протистояння факторам невизначеності, в контексті пізнання «сталого розвитку» як суспільного напряму і індикатору сталого науково-технологічного розвитку, направленого на зниження нестабільності.

\section{Література:}

1. Иноземцев В.Л. Теория постиндустриального общества как методологическая парадигма обществоведения / В.Л. Иноземцев // Вопросы философии, № 10, 1997. - с.34.

2. Сакайя Т. Стоимость, создаваемая знаниями, или история будущего // Новая индустриальная волна на Западе: Антология / под ред. В.Л. Иноземцева. - М.: Academia, 1999. - 632c.

3. Михнева С.Г. Интеллектуализация экономики: инновационное производство и человеческий капитал. / С.Г. Михнева // Журнал «Инновации» №1, 2003. c.12.

4. Penty A. Post-industrialism. London, $1922-485 p$.

5. Белл Д. Перехід постіндустріального суспільства / Д.Белл // Сучасна зарубіжна соціальна філософія - К.: Либідь, 1996. - с.214.

6. Маркс К. Теория прибавочной стоимости / К. Маркс. ч. III - c.127.

7. Bell D/ The Coming Post-industrial Society A.Venture in Social Forecasting - № 4, $1973-294 p$.

8. Белл Д. Грядуще постиндустриальное общество. Опыт социального прогнозирования / пер. с англ. Под ред. Иноземцева - М.: Academia, 1999. $949 \mathrm{c}$.

9. The global Competitiveness Report 2011-2012. [Електронний ресурс] - Way of access: http: // www.weforum.org/docs/WEF_GCR_Report_2011-2012.pdf.

10. Иноземцев В.Л. За пределами экономического общества / В.Л. Иноземцев M.: Academia, 1998. - 614c.

11. Гегель Георг Вильгельм Фридрих. Энциклопедия философских наук. Наука логики том.1. / Г.В.Д. Гегель. - М. Мысль. 1974. -452c.

12. Основи стійкого розвитку. Навчальний посібник / За заг. ред., д.е.н., проф. Л.Г. Мельника. - Суми: ВТД «Університетська книга», 2005. - 654c. 


\section{Literatura:}

1. Inozemcev V.L. Teorija postindustrial'nogo obshhestva kak metodologicheskaja paradigma obshhestvovedenija / V.L. Inozemcev // Voprosy filosofii, № 10, 1997. s.34.

2. Sakajja T. Stoimost', sozdavaemaja znanijami, ili istorija budushhego // Novaja industrial'naja volna na Zapade: Antologija / pod red. V.L. Inozemceva. - M.: Academia, 1999. - 632s.

3. Mihneva S.G. Intellektualizacija jekonomiki: innovacionnoe proizvodstvo i chelovecheskij kapital. / S.G. Mihneva // Zhurnal «Innovacii» №1, 2003. - s.12.

4. Penty A. Post-industrialism. London, $1922-485$ p.

5. Bell D. Perekhid postindustrial'noho suspil'stva / D.Bell // Suchasna zarubizhna sotsial'na filosofiia - K.: Lybid', 1996. - s.214.

6. Marks K. Teorija pribavochnoj stoimosti / K. Marks. ch. III - s.127.

7. Bell D. Grjadushhe postindustrial'noe obshhestvo. Opyt social'nogo prognozirovanija / per. s angl. Pod red. Inozemceva - M.: Academia, 1999. - 949s.

8. The global Competitiveness Report 2011-2012. [Електронний ресурс] - Way of access: http: // www.weforum.org/docs/WEF_GCR_Report_2011-2012.pdf.

9. The global Competitiveness Report 2011-2012. [Електронний ресурс] - Way of access: http: // www.weforum.org/docs/WEF_GCR_Report_2011-2012.pdf.

10. Inozemcev V.L. Za predelami jekonomicheskogo obshhestva / V.L. Inozemcev M.: Academia, 1998. $-614 \mathrm{~s}$.

11. Gegel' Georg Vil'gel'm Fridrih. Jenciklopedija filosofskih nauk. Nauka logiki tom.1. / G.V.D. Gegel'. - M. Mysl'. 1974. - 452s.

12. Osnovy stijkoho rozvytku. Navchal'nyj posibnyk / Za zah. red., d.e.n., prof. L.H. Mel'nyka. - Sumy: VTD «Universytets'ka knyha», 2005. - 654s. 